
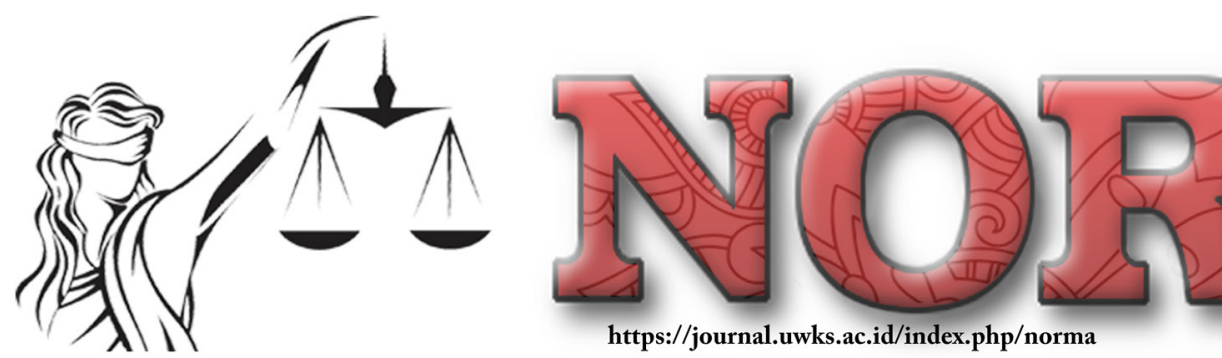

\title{
Legal Analysis of Universitas Wijaya Kusuma Surabaya Tower II Building Construction Agreement Between Wijaya Kusuma Foundation and PT Sinar Waringin Adikarya
}

\author{
Sulistiyo \\ Legal Observer \\ e-Mail: martiosulistiyo1976@yahoo.com
}

\begin{abstract}
:
In this study, researchers used the title Legal Analysis the Implementation of the Tower II Building Construction Agreement Wijaya Kusuma Surabaya University with PT SINAR WARINGIN ADIKARYA. This research was conducted To find out and analyze: Rights and Obligations of each party in the Towering Contract (Construction Contract) of Tower II Building, Universitas Wijaya Kusuma Surabaya, the form of the responsibilities of each party in the contracting contract (Construction Contract) Tower II Building, Universitas Wijaya Kusuma Surabaya, if one party makes a mistake. From the results of the analysis conducted in this study, the researcher states that: Rights and obligations must be carried out by each party as stated in the work implementation agreement as contained in Attachment to the work implementation agreement Number: 597/WK/XII/2017, as stated in Article 3 of the agreement when referred to as a second party's obligation it means the right of the first party, among others, to carry out the work carefully, accurate and complete responsibility by providing experts and other personnel, materials, equipment needed for the implementation of the work. The responsibilities that must be carried out in this work implementation agreement must be guided by the provisions of the agreement as referred to in the Attachment to the work implementation agreement Number: 597/WK/XII/2017, namely contained in article 4, article 6 , article 7 , article 8 , and article 11.
\end{abstract}

Keywords: Agreement; Construction; University.

Article's History:

Received:

June 9, 2021;

Peer-Reviewed:

June 21, 2021;

Accepted:

July 15, 2021;

Published:

July 30, 2021.

DOI:

10.30742/nlj.v18i2.1586

\section{INTRODUCTION}

Human development has been around for centuries. Development is an effort to create prosperity and welfare because it can be said that the law relates to chartering and buildings as old as human civilization. If the building was erected by someone else, then the basic principles of law, contracting and building can be applied even though the form is straightforward.

The realization of a just and prosperous society based on Pancasila and the 1945 Constitution of the Republic of Indonesia, development activities both in physical and non-physical development play an essential role in the welfare of the Indonesian nation. The development of the physical sector in Indonesia is in the form of construction of 
projects, both facilities and infrastructure in the form of construction and rehabilitation of roads, bridges, ports, irrigation, waterways, university buildings, residential buildings, hospitals, as well as government and private offices. The development is carried out both at the center and in the regions; this is very closely related to the principles of justice and equity as one of the principles of national development.

The development of contracts regarding the construction of the building is very rapid and complex, so the law of contracting continues to develop throughout the ages until now. However, all people must enjoy the results of development as a manifestation of increasing welfare both physically and mentally in a just manner and achieving prosperity. Likewise, if development can succeed, it depends on the participation of all people, meaning that development is carried out by all people equally by all levels of society. "The National Long-Term Development Plan (RPJP) as regulated in the Law of the Republic of Indonesia Number 17 of 2007 is a national development planning document which is a description of the objectives of the establishment of the Government of the State of Indonesia as stated in the Preamble to the 1945 Constitution of the Republic of Indonesia in the form of vision, mission and direction of national development for the next 20 years covering the period from 2005 to 2025".

Development in the physical field is currently developing in line with the needs of society, advances in science and technology. Therefore, physical development such as school buildings, toll roads, hospitals, and others is an object of the building contract law. Law Building contract agreement in the legal system is one element of building law (bouwrecht). The building has a broad meaning, namely: everything that is built on a plot of land. Building law is the entire set of laws and regulations relating to buildings, including establishment, maintenance, demolition, delivery, civil and public.

In Indonesia, these physical development projects are carried out by the government, domestic and foreign private sectors. Although in its implementation, only a tiny part is handled by the government, the rest is highly expected the participation of the private sector, both as investors and as contractors. In carrying out the work, the contractor works with a job chartering system. This makes the contractor referred to as a partner because the contractor is equated with co-workers. Based on the origin of the work, the chartering of work can be divided into two types of contracting agreements:

1. Work contracting agreements sourced from the government for the procurement of goods and services are carried out through an auction process as regulated by Presidential Decree Number 80 of 2003 concerning Guidelines for the Implementation of Government Procurement of Goods/Services;

2. A Contracting work agreement originating from the country is obtained directly due to a contract between the assignor (state) and the contractor (private).

The wholesale work originating from the state and carried out by the construction service company (contractor) must be done in an agreement and or contract that 
can bind both parties in outline; the Indonesian civil law order provides the most comprehensive opportunity for the community to make agreements. About anything according to its purpose. As the provisions of Article 1338 of the Civil Code reads as follows that every contract created by the parties can be validly the same as the law for the parties who make it. ${ }^{1}$

Auctions/tenders, which are regulated in Article 17 of Law Number 18 of 1999, as amended by Law of the Republic of Indonesia Number 2 of 2017 concerning Construction Services, Tenders/auctions are a series of activities to provide goods and or services needed balanced and meet the requirements, based on specific regulations determined by the relevant parties. This auction/tender can be participated by all construction service providers (contractors) who meet the public tender requirements with post-qualification or who have passed the pre-qualification. However, the description of construction agreements/contracts in Indonesia today still positions the Service Provider weaker than the Service User. In other words, the position of the Service User is more dominant than the position of the Service Provider.

This is due to an imbalance between the limited number of construction work/ projects and many service providers/contractors. Service users/parties who buy out the goods can choose the service provider to be given a tender/project with many service providers. After the auction/tender is carried out and the winner is selected, the service user issues a letter of appointment for the service provider. Finally, an agreement is made between the two parties in a work charter agreement (construction contract). ${ }^{2}$

According to Law Number 40 of 2007 concerning Limited Liability Companies (from now on referred to as UUPT), Article 1 number 1 states that Limited Liability Company is a legal entity which is a capital partnership established based on an agreement, conducting business activities with authorized capital which is entirely divided into shares and shares. Therefore, please comply with the requirements stipulated in this law and its implementing regulations.

PT SINAR WARINGIN ADIKARYA as a company engaged in construction services in the city of Surabaya, in terms of this agreement as a party related to the construction work with the foundation, of course, we see that there is a legal relationship between PT SINAR WARINGIN ADIKARYA (contractor) and the job contracting foundation. The legal relationship between the two parties is a civil law relationship so that both parties have the same legal position and position in the contract agreement.

In the implementation of the agreement between PT SINAR WARINGIN ADIKARYA and the employer, it has been going well. However, in reality, there are some differences in interests in the field related to the accountability of the parties. Problems that often arise are related to the time limit for completing the contract. As a

${ }^{1}$ Fani Martiawan Kumara Putra, “Urgensi Batasan Atau Pengendalian Asas Kebebasan Berkontrak Pada Peristiwa Pre Project Selling," Perspektif 24, no. 1 (2019): 30-36.

${ }^{2}$ Djumialdji, Hukum Bangunan (Jakarta: Rineka Cipta, 1996), 21. 
result, the contractor, namely PT SINAR WARINGIN ADIKARYA, has not been able to complete the work, which will hinder the completion of the work carried out. In addition, problems can also arise from the building contractor, namely the Wijaya Kusuma Foundation, regarding the completion of payments that have been scheduled as agreed, especially in the building contracting agreement, which has been completed with all of the agreed timeframes. Still, the building contractor has not fulfilled its obligation to pay what has been obtained or agreed.

This is very likely to happen because the construction work obtained by PT SINAR WARINGIN ADIKARYA tends to be based on the trust of the building contractor to PT SINAR WARINGIN ADIKARYA because of the relationship that has been well established. These differences in interests have become a problem between PT SINAR WARINGIN ADIKARYA and the building contractor, namely the Wijaya Kusuma Foundation.

It is impossible always to follow the existing laws and regulations in making and implementing the contractual agreement. Sometimes the contracts that are made, the form and content are not following the standards of contract making. Therefore, in its implementation, there is also the possibility of breach of contract/default. ${ }^{3}$ So if there is one of the parties, there is a default in implementing this chartering agreement. Recognizing the importance of solving this problem, the author will discuss implementing the building contract work agreement, the Rights, Obligations and the Respective Responsibilities of Tower II Universitas Wijaya Kusuma Surabaya Building Construction Contract Parties

\section{RESEARCH METHOD}

This research is normative legal research with a statutory approach.

\section{DISCUSSION}

Before agreeing, in general, the parties first enter into negotiations. At this stage of the talks, the material from the agreement is discussed by the parties, specifically regarding the work agreement for building construction held by the party providing the work. This auction procedure is more commonly known as the stage that precedes the occurrence of the agreement. If the chartering is carried out through an auction, several processes will be passed, including:

1. Notification/announcement in general or in a limited way regarding the existence of a job auction, an explanation of the work following the job requirements;

2. Pre-qualification, qualification and post-qualification requirements for contractors;

${ }^{3}$ H. Nazarkhan Yasin, Mengenal Kontrak Konstruksi Di Indonesia (Jakarta: Gramedia Pustaka Utama, 2003), 245. 
3. Fulfilment of guarantees that are guaranteed in building contracting, tender guarantees, implementing guarantees, down payment guarantees, maintenance guarantees, development guarantees, guarantee contracts, and guarantee disbursement;

4. The auction includes a public auction, a limited auction and the method of determining graduation. ${ }^{4}$

After the process is complete, the winner and the employer then make a building construction work agreement, the contents of which regulate the main points of work in detail and the conditions for implementing the work. Through a negotiation system, the selection of contractors is not carried out by a particular tender. Still, the party providing the building construction work negotiates directly with the contractor and can be selected to carry out the work in question. This negotiation procedure is informal. ${ }^{5}$

In terms of this form of negotiation, we can see freedom of contract as an essential principle in the agreement. Negotiations that show a balanced position are between the employer and the contractor. Negotiations in the chartering agreement are an initial agreement but are not yet a contractual agreement. Therefore, after the negotiation stage, the parties will put it in a written contract that contains details of the rights and obligations, the terms of work and the period of implementation of the building construction work agreement, and other matters deemed necessary by the parties.

Based on Article 1 point (8) of Law Number 2 of 2017 concerning Construction Services, it is stated that the construction work contract is the entire contract document that regulates the legal relationship between service users and service providers in the implementation of construction services. Therefore, the construction work contract is made separately according to the stages in the construction work, which consists of a construction work contract for planning work, implementation and supervision work.

According to the provisions of Article 39 of Law Number 2 of 2017 concerning Construction Services, the parties participating in the construction agreement consist of service users and service providers. The service user is the owner or employer who uses construction services, while the service provider is the construction services provider. (General Provisions of Law Number 2 of 2017 concerning Construction Services) Construction work contracts are subject to applicable laws in Indonesia. Their form can follow the development of needs and are carried out according to the provisions of laws and regulations. Based on Government Regulation No. 29/2000, construction work contracts are distinguished based on Article 23 paragraph (6) of Government Regulation No. 29 of 2000 concerning the Implementation of Construction Services, namely:

${ }^{4}$ Sri Soedewi Maschjun Sofyan, Hukum Bangunan Perjanjian Pemborongan Bangunan (Jogyakarta: Liberty, 1982), 8.

${ }^{5}$ Munir Fuady, Kontrak Pemborongan Mega Proyek (Bandung: Citra Aditya Bakti, 1998), 175. 
1. The form of compensation, which consists of a lump sum, unit price, additional fees for service fees, a combination of lump sum and unit price, or an alliance;

2. The period of execution of construction work, which consists of a single year, or multiple years;

3. How to pay for the results of work, namely according to the progress of work or periodically.

In Article 47 paragraph (1) of Law Number 2 of 2017 concerning Construction Services, it is stated that: A construction work contract must at least include a description of:

1. The parties clearly state the identity of the parties;

2. Job formulation, containing a clear and detailed description of the scope of work, work value, unit price, lump sum, and implementation time limit;

3. The period of coverage contains the implementation and maintenance period, which is the responsibility of the Service Provider;

4. Equal rights and obligations, containing the rights of service users to obtain construction services and their obligations to fulfil the agreed terms, as well as the rights of service providers to obtain information and compensation for services as well as their obligations to carry out construction services;

5. The use of construction workers, containing the obligation to employ certified construction workers;

6. Method of payment, containing provisions regarding the obligations of service users in making payments for the results of construction services, including guarantees for payments;

7. Default contains provisions regarding liability if one of the parties does not carry out the obligations as agreed;

8. Settlement of disputes, containing provisions on procedures for resolving disputes due to disagreements;

9. Termination of construction work contracts, containing provisions regarding termination of construction work contracts arising from non-fulfilment of the obligations of one of the parties;

10. Forced circumstances, containing provisions regarding events that arise against the will and ability of the parties that cause harm to one of the parties;

11. Building failure, containing provisions concerning the obligations of service providers and/or service users for building failures and the period of responsibility for building failures;

12. Protection of workers, containing provisions regarding the obligations of the parties in the implementation of occupational safety and health as well as social security;

13. Protection of third parties other than the parties and workers contains the obligations of the parties in the event that causes loss and/or death; 
14. The environmental aspect contains the obligations of the parties in fulfilling the provisions concerning the environment;

15. Guarantees for risks that arise and legal liability to other parties in the implementation of construction work or as a result of building failures; and

16. Construction dispute resolution options.

An agreement is an event where one person promises to another person or where the two people promise each other to carry out something. From this event, a relationship arises between the two people, which is called an engagement. ${ }^{6}$ Based on Article 1320 of the Civil Code, the conditions for a valid agreement are:

1. Agree on those who bind him;

2. Ability to Make an Agreement;

3. A Certain Thing;

4. A Non Prohibited Cause.

Two conditions, (a) and (b), are subjective conditions and (c) and (d) are objective conditions. Accordingly, the Deed of Agreement which both parties have agreed to write in the deed are: ${ }^{7}$

1. In connection with the following information, on Tuesday the nineteenth of December in the year two thousand and seven, we, the undersigned, agreed to implement the building construction work. The parties explain that they have mutually agreed and agreed to agree with the deed at this moment by using the terms and conditions in the following article and its attachments;

2. Whereas the second party undertakes to carry out the construction work of the office building and stage IV lectures at the Universitas Wijaya Kusuma Surabaya following the work plan and conditions (RKS) and carried out at the place of duty according to the provisions;

3. That the parties intend to put their intentions and intentions into this deed.

Conditions (c) and (d) are objective conditions in which the object listed in the agreement must exist and be lawful, halal in question is not against article $1337 \mathrm{BW}$, namely a cause is prohibited, if it is prohibited by law, or if it is contrary to decency excellent or public order, as stated in Article 12. Therefore, the objects of the agreement made by the first and second parties that are written in the agreement deed are:

1. A plot of land directly owned by the Wijaya Kusuma Foundation covering an area of approximately 1,083 M2 located at Jalan Dukuh Kupang Barat I/31 East Java Province, Surabaya City, Dukuh Pakis District;

2. The land is the property and property of the first party, which can be proven by a deed that has been made previously;

3. Buildings will be built according to the nature and provisions of the law;

${ }^{6}$ Subekti, Hukum Perjanjian (Jakarta: Intermasa, 1987), 1.

${ }^{7}$ Fani Martiawan Kumara Putra, "Characteristics of Notary Deeds for Transactions Through Electronic Media," NORMA 17, no. 3 (January 14, 2021): 1-14, https://doi.org/10.30742/nlj.v17i3.1091. 
4. The second party undertakes at the expense of the first party to build an office building and stage IV lectures at Universitas Wijaya Kusuma Surabaya on land owned by the first party.

Accountability of the parties in the contracting agreement for the implementation of work must be considered to get the building construction work as expected by the parties. The responsibilities imposed on the first party in the work implementation agreement include the provision of land or land whose legal certainty is guaranteed; provide adequate financing following the agreement; this is following article 4 paragraph (2) of the Work Implementation Agreement Number 597/WK/XII/2017 concerning the Value of Work and Payment Methods, namely: Payment of the value of work in paragraph (1) of this article is carried out in stages following the work performance that has been completed. Approved/ratified by the first party with the following details: a. Advance payment is paid 10\% of the work price after the second party submits a written application accompanied by a down payment guarantee (from a state bank or other financial institution determined by the minister of finance). The down payment guarantee is valid until the full refund of the advance is paid off. $b$. The following term/instalment is paid every month with minimum progress of $6 \%$ and deducted from the refund of advances and retention following the progress submitted. Payment of each instalment is carried out within a maximum period of 7 (seven) working days after all requirements and receipts are received by the first party and transferred to the account of PT. Sinar Waringin Adikarya, through Bank Rakyat Indonesia; ensure that there are disturbances related to the implementation of development work, this is as stated in Article 6 of the Work Implementation Agreement Number 597/WK/ XII/2017 concerning work added and less, as follows: (1) deviations and/or changes which are additions or reductions of work, are only considered valid after receiving a written order from the first party by clearly stating the type and details of the work. (2) the calculation or reduction of work is carried out based on a price agreed by both parties if it is not listed in the price list for the work unit. (3) The existence of additional work cannot be used as a reason to change the time of completion of the work, except with the written approval of the first party.

Furthermore, Article 7 of the Work Implementation Agreement Number 597/ WK/XII/2017 concerning Fines and Compensation Paragraph (4) states that: The amount of compensation that the first party must pay for late payment is the amount of interest on the value of the late payment bill, based on the interest rate on the value of overdue claims based on the prevailing interest rate at that time according to the provisions of Bank Indonesia or compensation can be given following the provisions in the employment agreement document.

Likewise, the responsibility of the first party must provide field supervisors, as stated in Article 8 of the Work Implementation Agreement Number 597/WK/XII/2017 
concerning Field Supervisors, namely: (1) In supervising the implementation of work, the first party appoints a team of directors as consultants for the work supervisor. construction of office buildings and lectures Phase IV (Green Tower II) Universitas Wijaya Kusuma Surabaya. The liability that the second party must carry out can be explained as follows:

1. In line with Article 1 of the Work Implementation Agreement Number 597/ WK/XII/2017, regarding the scope of work, paragraph (1) states that: the second party must carry out the construction work of office buildings and lectures phase IV (Green Tower II) Universitas Wijaya Kusuma Surabaya following the work plan and conditions (RKS) and carried out at the place of duty following the provisions;

2. If the second party neglects its responsibilities, the second party is responsible for the imposition of fines that must be paid to the first party. This is as stated in Article 7 of the work implementation agreement Number 597/WK/XII/2017, paragraph (1) which states that: Fines are financial sanctions imposed on a second party, paragraph (2) states that: If the second party after obtaining written warning 3 (three) times in a row and ignoring the obligations as stated in terms of the contract, every time the second party carries out activities, the second party must pay a negligence fine of $10 / 00$ (one per mil) of the price of the work, with a maximum a fine of $5 \%$ (five percent) of the contract price;

3. Second-party liability must provideexperienced workers in carrying outbuilding construction work. This is as stated in Article 8 of the Work Implementation Agreement Number 597/WK/XII/2017 paragraph (2), namely: the second party must determine the full-time work of experienced personnel following the work carried out and must notify in writing the first party, and the first party has the right to refuse workers who do not meet the requirements;

4. The second party is responsible for all payments for stamp duty and taxes. This is following Article 11 of the Work Implementation Agreement Number 597/WK/XII/2017, which states that: the stamp duty and taxes incurred, with the existence of this work agreement, are the burden and responsibility of the second party. The form of responsibility from the first party is absolute and is an obligation that should not be countered. If it is not implemented, it will hinder the implementation of development.

\section{CLOSING}

\section{Conclusion}

That the rights and obligations that must be carried out by each party as stated in the work implementation agreement as contained in the Attachment to the Work Implementation Agreement Number: 597/WK/XII/2017, as stated in Article 3 of the 
agreement, when referred to as the obligations of the second party, it means as the right of the first party, among others, to carry out work carefully, accurately and responsibly by providing experts and other personnel, materials, equipment needed for the implementation of the work. And that the accountability that must be carried out in this work implementation agreement, the parties must be guided by the provisions of the agreement letter as referred to in the Attachment to the Work Implementation Agreement Number: 597/WK/XII/2017, which is contained in article 4, article 6, article 7, Article 8 and Article 11.

\section{Recommendation}

It is intended that the parties who agree should be obliged to comply with the applicable laws and regulations before the parties agree so that there is no prohibition from the authorities.

\section{REFERENCES}

Djumialdji. Hukum Bangunan. Jakarta: Rineka Cipta, 1996.

H. Nazarkhan Yasin. Mengenal Kontrak Konstruksi Di Indonesia. Jakarta: Gramedia Pustaka Utama, 2003.

Munir Fuady. Kontrak Pemborongan Mega Proyek. Bandung: Citra Aditya Bakti, 1998.

Putra, Fani Martiawan Kumara. "Characteristics of Notary Deeds for Transactions Through Electronic Media." NORMA 17, no. 3 (January 14, 2021): 1-14. https:// doi.org/10.30742/nlj.v17i3.1091.

- - - "Urgensi Batasan Atau Pengendalian Asas Kebebasan Berkontrak Pada Peristiwa Pre Project Selling." Perspektif 24, no. 1 (2019): 30-36.

Sri Soedewi Maschjun Sofyan. Hukum Bangunan Perjanjian Pemborongan Bangunan. Jogyakarta: Liberty, 1982.

Subekti. Hukum Perjanjian. Jakarta: Intermasa, 1987. 